\title{
Genetic variation in Phoca vitulina (the harbour seal) revealed by DNA fingerprinting and RAPDs
}

\author{
A. L. KAPPE*, L. VAN DE ZANDE, E. J. VEDDER†, R. BIJLSMA \& W. VAN DELDEN \\ Department of Genetics, University of Groningen, Kerklaan 30, NL-9751 NN Haren (GN) and $\dagger$ Seal Rehabilitation and \\ Research Centre, Hoofdstraat 94a, NL-9968 AG Pieterburen. The Netherlands
}

\begin{abstract}
Genetic variation in two harbour seal (Phoca vitulina) populations from the Dutch Wadden Sea and Scotland was examined by RAPD analysis and DNA fingerprinting. For comparison a population of grey seals (Halichoerus grypus) was studied. The RAPD method revealed a very low number of polymorphic bands. The multilocus DNA fingerprinting technique showed very low levels of variation both within and between populations of the harbour seals. For one probe a significant difference in variation between populations was demonstrated. The estimated average heterozygosity, however, diverged more strongly between the two harbour seal populations because of more frequent occurrence of rare alleles in the Scottish population. Low levels of genetic variation seem to be characteristic for the subspecies Phoca vitulina vitulina, but not for all marine mammals in the North Sea, as the grey seal population showed significantly higher variation.
\end{abstract}

Keywords: conservation genetics, DNA fingerprinting, genetic variation, harbour seal.

\section{Introduction}

The destruction and fragmentation of natural habitats leads to small scattered populations that can be completely isolated (Wilcove et al., 1986). In such small populations genetic drift and inbreeding will cause the loss of genetic variation and an increase in homozygosity. This may result in a severe reduction in fitness characters (inbreeding depression), such as reproductive capacity, and in a decreased adaptive potential. Inbreeding depression is thought to be an important factor in the extinction of endangered species (Frankel \& Soulé, 1981; Schonewald-Cox et al., 1983; Soulé, 1987). The combined negative effects of isolation and small population size on genetic variation is called 'genetic erosion' (van Treuren, 1993). To investigate the amount of genetic erosion in endangered animal populations we have started a project to investigate the genetic variation in different populations of the harbour seal (Phoca vitulina) and in a population of a related species, the grey seal (Halichoerus grypus) which lives in the same habitat.

The harbour seal in the Dutch Wadden Sea suffered a strong decline in population size until the mid-1970s. The population size was reduced from 2500 individ-

*Correspondence. uals in the 1940 s to only 500 animals in the 1970 s (Reijnders, 1980). Because of protective strategies the population started to recover in the early 1980 s but a recent epidemic viral infection strongly reduced the population size again to about 500 animals in 1987 (Reijnders \& Lankester, 1990).

A previous study to determine the amount of genetic variation in the Dutch harbour seal population by allozyme electrophoresis revealed the complete absence of genetic variation at 24 loci tested (J. A. A. Swart \& W. van Delden, unpublished data). A similar absence of allozyme variation has been observed in other large animals that have gone through a bottleneck, such as the Northern elephant seal (Bonnell \& Selander, 1974) and the African cheetah (O'Brien et al., 1985).

In this study the Random Amplified Polymorphic DNA (RAPD) method (Williams et al., 1990) and the multilocus DNA fingerprinting technique (Jeffreys et al., 1985a) were used to assess the level of genetic variation. Both these methods usually reveal higher levels of genetic variation at the DNA level. In particular, the DNA fingerprinting technique is extremely sensitive and revealed a substantial amount of genetic variation in two populations of the African cheetah while none had been detected by allozyme electrophoresis (Gilbert et al., 1991). Moreover, DNA fingerprinting has been able to provide insight in the genetic 
structure of populations with low levels of genetic variation (Reeve et al., 1990; Hoelzel \& Dover, 1991; van Pijlen et al., 1991; Brock \& White, 1992).

To establish whether genetic erosion has occurred in the small Dutch population of harbour seals, we assessed the amount of genetic variation in two populations of harbour seals from geographically separated areas; a relatively small population of about 1000 individuals (Reijnders et al., 1989) in the Dutch Wadden Sea and a large population of about 25000 individuals (Harwood, 1987) in Scotland. In addition, the genetic variation in grey seals, a small population of about 100 animals in the Dutch Wadden Sea, was determined to compare two related species from the same habitat.

\section{Materials and methods}

\section{Samples}

Two populations of harbour seals were examined. Twenty-six animals were obtained from the Dutch Wadden Sea between August 1992 and March 1993. Twenty animals were obtained in 1988 from the East coast of Scotland. Because both populations are separated by the North Sea, gene flow between the two populations is expected to be restricted (P. J. H. Reijnders, personal communication). For comparison at the species level, samples from 14 grey seals (Halichoerus grypus), caught in the Dutch Wadden Sea, were also analysed.

All blood samples were collected at the Dutch Seal Rehabilitation and Research Centre in Pieterburen, where the animals were in temporary captivity.

\section{Laboratory procedures}

DNA extraction Genomic DNA was extracted from 5 $\mathrm{mL}$ blood collected in EDTA anticoagulant vacutainers (Venoject; Terumo). Nucleated cells were isolated and $1 \mathrm{~mL}$ lysis-buffer ( $10 \mathrm{~mm}$ Tris- $\mathrm{HCl}, \mathrm{pH} 7.4$, $100 \mathrm{~mm} \mathrm{NaCl}, 25 \mathrm{~mm}$ EDTA, pH, 8.0, 0.5 per cent SDS (w/v) and $100 \mu \mathrm{g} / \mathrm{mL}$ proteinase $\mathrm{K}$ ) was added, tubes were shaken gently and incubated overnight at $55^{\circ} \mathrm{C}$. The DNA was purified by two extractions with phenol and two chloroform/isoamyl-alcohol extractions (24:1) (Kirby, 1990).

$R A P D$ method RAPD reactions were performed essentially as described by Williams et al. (1990). Briefly, the reaction was performed in a volume of 25 $\mu \mathrm{L}$ containing $2.5 \mu \mathrm{L} 10 \times$ Taq buffer (Promega), 100 $\mu \mathrm{M}$ dNTPs (Pharmacia), $16.5 \mathrm{ng}$ primer (10-mer Operon), $30 \mathrm{ng}$ genomic DNA and 1 unit Taq DNA polymerase (Promega). Amplification was carried out in a Perkin Elmer Cetus DNA Thermal Cycler programmed for $3 \mathrm{~min}$ at $94^{\circ} \mathrm{C}$ followed by 40 cycles of 1 min at $94^{\circ} \mathrm{C}, 1 \mathrm{~min}$ at $36^{\circ} \mathrm{C}$ and $2 \mathrm{~min}$ at $72^{\circ} \mathrm{C}$. Amplified DNA fragments were resolved by electrophoresis in a 2 per cent agarose gel containing $0.5 \mu \mathrm{g} / \mathrm{ml}$ ethidium bromide. Bands were visualized by UV transillumination.

DNA fingerprinting Five micrograms of DNA were digested overnight with 15 units of the restriction enzyme HinfI. The resulting DNA fragments were separated by electrophoresis in a 0.8 per cent agarose gel containing $0.5 \mu \mathrm{g} / \mathrm{mL}$ ethidium bromide, in TBEbuffer $(0.089 \mathrm{M}$ Tris, $0.089 \mathrm{M}$ boric acid, $0.002 \mathrm{M}$ EDTA) for $40 \mathrm{~h}$ at $1.5 \mathrm{~V} / \mathrm{cm}$. The DNA fragments were transferred by vacuum-blotting to nylon membranes (Hybond-N, Amersham) and crosslinked by UV light.

Human minisatellite probes 33.6 and 33.15 (Jeffreys et al., 1985b) were labelled with $\left[\alpha^{32} \mathrm{P}\right] \mathrm{dCTP}$ by the random primer method (Feinberg \& Vogelstein, 1983). The filters were prehybridized for $1 \mathrm{~h}$ at $65^{\circ} \mathrm{C}$ in a solution containing 7 per cent SDS (w/v), $1 \mathrm{~mm}$ EDTA and $0.263 \mathrm{M} \mathrm{Na}_{2} \mathrm{HPO}_{4}$, pH 7.2 (Westneat et al., 1988). Hybridization to the probe was carried out in the same solution overnight at $65^{\circ} \mathrm{C}$. Filters were washed with $2 \times \mathrm{SSC}$ ( $300 \mathrm{~mm} \mathrm{NaCl} ; 30 \mathrm{~mm} \mathrm{Na}$ citrate, $\mathrm{pH} 8$ ), 0.1 per cent SDS $(\mathrm{w} / \mathrm{v})$ for $5 \mathrm{~min}$ at room temperature and for $15 \mathrm{~min}$ at $65^{\circ} \mathrm{C}$. They were then autoradiographed for 2-5 days at $-70^{\circ} \mathrm{C}$ using Kodak X-OMAT X-ray film and two intensifying screens.

\section{Statistical analysis}

The fingerprints were analysed manually. All clear bands in the range from 2.5 to $9 \mathrm{~kb}$ were scored. The coefficient of band-sharing between individuals was calculated as $S_{x y}=2 n_{x y} /\left(n_{x}+n_{y}\right)$, where $n_{x}$ and $n_{y}$ are the numbers of bands present in individuals $x$ and $y$, respectively, and $n_{x y}$ is the number of bands shared by $x$ and $y$ (Wetton et al., 1987).

In estimations of population similarities individuals are used in multiple comparisons, therefore the data are not independent (Lynch, 1990). Mean population similarity was estimated by averaging the similarities of all pairs of individuals in the sample. The standard error of this mean was estimated by the method of Lynch (1990), which does not only consider variances but also covariances between similarity indices. Variance was estimated using all overlapping pairs of individuals. Covariance of overlapping similarities was estimated using all possible pairwise combinations sharing one individual. Differences between band- 
sharing coefficients were tested by a two-tailed $t$-test $(P<0.05)$.

The average heterozygosity was estimated according to Stephens et al. (1992) as $H=\left[\Sigma s_{k} /(A-\Sigma /(1-\right.$ $\left.\left.\left.s_{k}\right)\right)\right]-1$, where $s_{k}$ is the frequency of the $k$ th fragment in the sample, and $A$ is the total number of fragments observed overall at polymorphic and monomorphic loci.

\section{Results}

In two populations of the harbour seal the RAPD method was tested with 50 randomly chosen primers, of which 25 generated amplified fragments. The average number of bands with these primers was very low, 2.1 bands per primer. All individuals of both populations revealed an identical monomorphic pattern with 23 primers. Only two primers, OPG-12 (five bands; two polymorphic) and OPF-18 (11 bands; seven polymorphic), revealed polymorphic bands (Fig. 1).

The DNA fingerprinting technique revealed variable multibanded patterns. In Fig. 2(a) a selection of patterns of the harbour seal, from the Dutch Wadden Sea and Scotland, revealed by the human probe 33.15 is shown. Scorable bands were found ranging from 2.5 to $9 \mathrm{~kb}$ in both populations. In this range totals of 25 and 40 informative bands were resolved in the two harbour seal populations with probes 33.6 and 33.15, respectively. The hybridization patterns were reproducible and relative intensities of fragments did not vary between experiments. No common bands were found to be specific for a particular population of the harbour seal. However, in both populations bands that occurred in only a single animal were observed, in particular in the Scottish population.

The results of band-sharing analysis, both within and between populations of the harbour seal, are presented in Table 1. With Jeffreys probe 33.6 we found the band-sharing coefficient within the Dutch population to be 0.82 and within the Scottish population to be 0.83 , which is not significantly different. With probe 33.15 the band-sharing coefficients obtained within the populations, 0.87 for the Dutch and 0.79 for the Scottish population, were found to be significantly different. The band-sharing coefficients between the Dutch and Scottish populations were 0.80 and 0.81 for the two probes 33.6 and 33.15 , respectively, and are not significantly different.

In Fig. $2 \mathrm{~b}$ a selection of patterns (revealed by the probe 33.6) of the harbour seal and the grey seal is shown. A comparison of the bandsharing coefficients
Fig. 1 RAPD analysis of DNA from 12 Phoca vitulina individuals from Scotland (lanes 1-12) and 11 from the Wadden Sea (lanes 13-22, 24) and one Phoca groenlandica indicated by the arrow (lane 23), using a 10-mer primer OPF-18 (TTCCCGGGTT). Marker (lane $\mathrm{M}$ ) is lambda DNA-digested with BstEII.

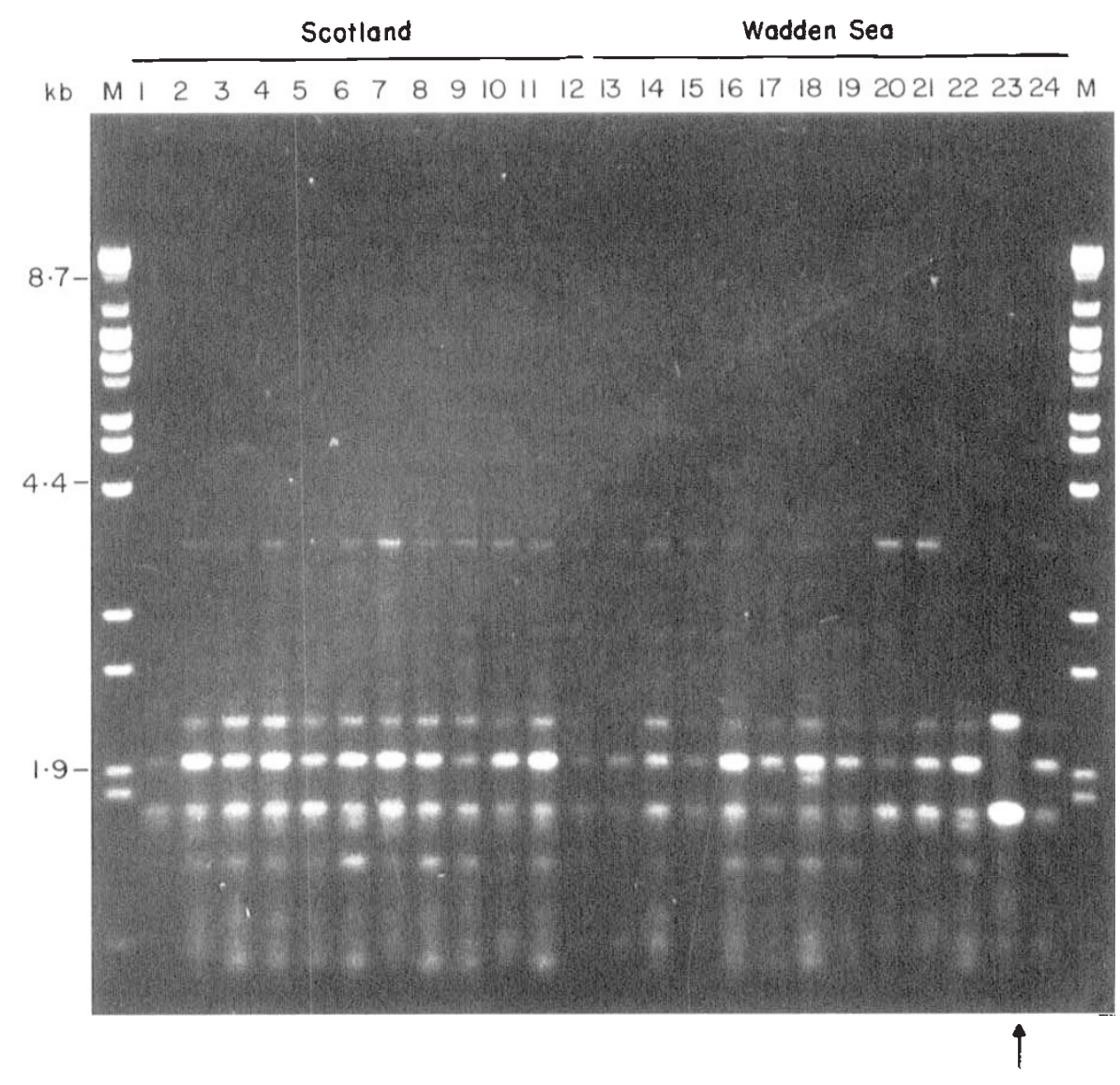

(c) The Genetical Society of Great Britain, Heredity, 74, 647-653. 


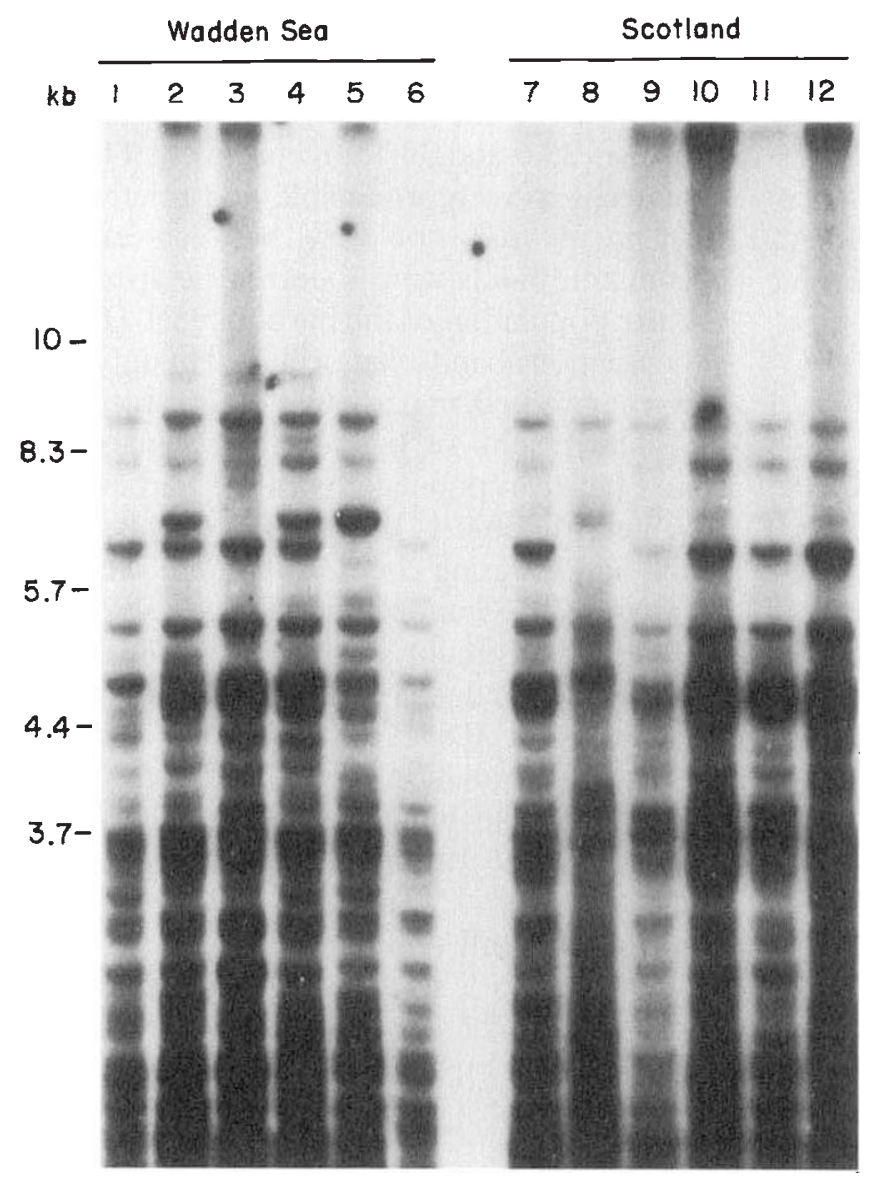

(a)

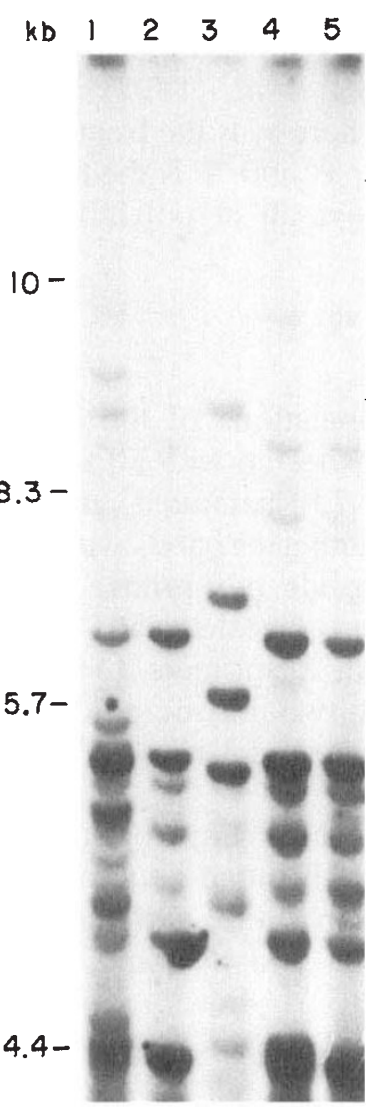

(b)

Fig. 2 DNA fingerprints of Phoca vitulina and Halichoerus grypus. (a) Representative patterns of $P$. vitulina; six individuals from the Dutch Wadden Sea (lanes 1-6) and six individuals from Scotland (lanes 7-12); DNA was digested with HinfI and hybridized with probe 33.15. (b) An example of an interspecies fingerprint; H. grypus individuals in lanes 1 and 3, and Phoca vitulina individuals in lanes 2, 4 and 5. DNA was digested with HinfI and hybridized with probe 33.6.

Table 1 Average band-sharing coefficients, $\bar{S}$, within and between populations detected by the multilocus probes 33.6 and 33.15 in the harbour seals

\begin{tabular}{lccc}
\hline Probe & $n$ & 33.6 & 33.15 \\
\hline $\begin{array}{l}\text { Within populations } \\
\quad \text { Wadden Sea }\end{array}$ & 26 & $0.82(0.02)$ & $0.87(0.01)$ \\
$\quad$ Scotland & 20 & $0.83(0.01)$ & $0.79(0.01)$ \\
$\begin{array}{l}\text { Between populations } \\
\quad \text { Wadden Sea } \times \text { Scotland }\end{array}$ & & $0.80(0.05)$ & $0.81(0.04)$ \\
\hline
\end{tabular}

$n$ : sample size.

Data are presented as mean values $\pm \mathrm{SE}$.

within and between the two seal species is presented in Table 2. In the range $2.5-9 \mathrm{~kb}$ totals of 28 and 39 informative bands were resolved for the grey seals with the probes 33.6 and 33.15 , respectively. Band-sharing coefficients for both probes within the grey seal were
Table 2 Comparison of band-sharing coefficients, $\bar{S}$, by multilocus probes 33.6 and 33.15 , between two seal species in the North Sea

\begin{tabular}{lccc}
\hline Probe & $n$ & 33.6 & 33.15 \\
\hline Within species & & & \\
$\quad$ Grey & 14 & $0.49(0.01)$ & $0.50(0.01)$ \\
$\quad$ Harbour & 46 & $0.82(0.07)$ & $0.82(0.05)$ \\
$\quad$ Between species & & & \\
$\quad$ Grey $\times$ harbour & & $0.37(0.19)$ & $0.48(0.14)$ \\
\hline
\end{tabular}

$n$ : sample size.

Data are presented as mean values $\pm \mathrm{SE}$.

calculated to be 0.49 and 0.50 , for probes 33.6 and 33.15 , respectively, and are significantly lower than the harbour seal values. The band-sharing coefficients between the two species, 0.37 and 0.48 for probes 33.6 and 33.15 , respectively, were not significantly different 
Table 3 Estimated average heterozygosities in harbour seal populations and grey seals by probes 33.6 and 33.15

\begin{tabular}{lll}
\hline Probe & 33.6 & 33.15 \\
\hline $\begin{array}{l}\text { Populations of harbour seal } \\
\quad \text { Wadden Sea }\end{array}$ & 0.21 & 0.18 \\
$\quad$ Scotland & 0.37 & 0.28 \\
Species & & \\
$\quad$ Harbour seal & 0.25 & 0.28 \\
$\quad$ Grey seal & 0.54 & 0.56 \\
\hline
\end{tabular}

from the band-sharing found within the grey seal, but were significantly lower than that found in the harbour seals. A number of bands specific for the two species were observed.

The estimated average heterozygosity values calculated from the fingerprint data are given in Table 3 . The Dutch harbour seal population showed lower estimated average heterozygosities, 0.21 and 0.18 for the probes, respectively, than the Scottish population, 0.37 and 0.28 , respectively. For both populations these estimated heterozygosities are quite low compared with the grey seal that showed a considerably higher estimated heterozygosity for both probes, 0.54 and 0.56 , respectively.

\section{Discussion}

The standard RAPD protocol, applied to the seal DNA, produced, on average, a low number of bands. Possibly more informative patterns could be obtained by modifying the conditions. However, as the first results of the RAPD analysis showed a very low number of polymorphic bands and thus revealed almost no variation we did not attempt to optimize the procedure.

In the DNA fingerprint analysis both Jeffreys human minisatellite probes, 33.6 and 33.15 , allowed the distinction between all individuals tested and showed many polymorphic alleles.

The statistical interpretation of fingerprint patterns is impeded by the fact that pairwise comparisons between patterns are not independent. Positive covariances between the entries of a similarity matrix might lead to an underestimate of standard errors and hence to unjustified conclusions concerning significant differences between populations. To correct for such potential biases, we used the method described by Lynch (1990) to estimate covariances between datapoints. However, the simplified version of this method, in which covariances are calculated using adjacent triplets on a gel, does not seem to be reliable for small sample sizes. In fact, in some cases we obtained negative values for the covariance and even for some of the standard errors. Therefore we estimated the sampling covariance by including all possible pairwise combinations sharing one individual; the sampling variance was estimated using all unique nonoverlapping pairs of individuals.

The degree of band-sharing found among the harbour seals, in both the Dutch Wadden Sea population and the Scottish population, was very high and indicates a low level of genetic variation, which is in agreement with the results found for allozymes in this species. These observations contrast with the high levels of variability generally reported by DNA fingerprinting with the same probes in, for example, humans (Jeffreys et al., 1985 a,b), birds (Burke \& Bruford, 1987), domestic mammals (Georges et al., 1988) and humpback whales (Baker et al., 1993). On the other hand, comparative surveys in geographically isolated and small populations of terrestrial mammals, such as the Channel Island fox (Gilbert et al., 1990), the Gir lion (Gilbert et al., 1991), mysticete whales (Amos \& Hoelzel, 1990; van Pijlen et al., 1991) and the Northern elephant seal (Hoelzel et al., 1993) revealed less variable DNA fingerprints. The extent of genetic variability at DNA fingerprint loci, given the high mutation rate of these loci (Jeffreys et al., 1988), may be strongly dependent on the timing of a population bottleneck (Ellegren et al., 1993; Hoelzel et al., 1993; Menotti-Raymond \& O'Brien, 1993).

For the two populations of the harbour seal hardly any significant differences were found in comparisons of the population similarities and no populationspecific fragments were found. This may indicate that the populations probably are not completely separated and some gene flow may occur.

Nevertheless, the estimated heterozygosities of the two harbour seal populations demonstrate a considerable divergence. The values obtained for the Scottish population were distinctly higher than those found for the Wadden Sea population, because of the more frequent occurrence of rare alleles in the Scottish population. This may reflect its larger population size. Even though it is difficult to obtain reliable estimates of variances of these heterozygosity estimates, they are observed to be generally very small (Stephens et al., 1992). It seems likely therefore that the observed differences in heterozygosity have a biological meaning. If this difference in homozygosity reflects a difference in effective population size, it could possibly explain why the Wadden Sea population suffered considerably more from a recent viral infection ( 60 per cent of the population died; Reijnders et al., 1989) than the Scottish population. 
The high band-sharing coefficients found indicate a low level of genetic variation in the subspecies Phoca vitulina vitulina in the North Sea. The level of genetic variation in this subspecies is very low compared with that of the grey seal (Halichoerus grypus). Possibly, the harbour seal in the North Sea has gone through one or more population bottleneck(s), but the grey seal has not. The differences found between the two species, however, could also reflect the differences in social organization, reproductive behaviour and mobility of the animals (Bonner, 1972).

Preliminary results indicate that a much higher level of genetic variation is present in the Eastern Pacific harbour seal (Phoca vitulina richardsii) (A. L. Kappe, unpublished data).

\section{Acknowledgements}

We thank the Dutch Seal Rehabilitation and Research Centre in Pieterburen for providing blood samples of the seals, especially A. Dijkens and laboratory personnel and P. J. H. Reijnders for support and helpful comments. We thank an anonymous reviewer and $\mathrm{F}$. J. Weissing for valuable comments on the statistics and $\mathrm{H}$. Mulder for preparing the illustrations.

\section{References}

AMOS, W. AND HOELzel, A. R. 1990. DNA fingerprinting cetacean biopsy samples for individual identification. Rep. Int. Whaling Comm., Special issue 12, 79-86.

BAKER, C. S., GILBERT, D. A., WEINRICH, M. T., LAMBERTSEN, R., CALAMBOKIDIS, J., MCARDLE, B., CHAMBERS, G. K. AND O'BRIEN, S. J. 1993. Population characteristics of DNA fingerprints in Humpback whales (Megaptera novaeangliae). J. Hered., 84, 281-290.

BONNELL, E. H. AND SELANDER, R. K. 1974. Elephant seals: genetic variation and near extinction. Science, 184, 908-909.

BONNER, W. N. 1972. The grey seal and common seal in European waters. Oceanogr. Mar. Biol. Ann. Rev., 10, 461-507.

BROCK, M. K. AND WHITE, B. N. 1992. Application of DNA fingerprinting to the recovery program of the endangered Puerto Rican parrot. Proc. Natl. Acad. Sci. U.S.A., 89, 11121-11125.

BURKE. T. AND BRUFORD, M. w. 1987. DNA fingerprinting in birds. Nature, 327, 149-152.

ELLEGREN, H., HARTMAN, G., JOHANSSON, M. AND ANDERSSON, L. 1993. Major histocompatibility complex monomorphism and low levels of DNA fingerprinting variability in a reintroduced and rapidly expanding population of beavers. Proc. Natl. Acad. Sci. U.S.A., 90, 8150-8153.

FEINBERG, A. P. AND VOGELSTEIN, B. 1983. A technique for radiolabelling DNA restriction endonuclease fragments to high specific activity. Analyt. Biochem., 132, 6-13.
FRANKEL, O. H. AND SOULE, M. E. 1981. Conservation and Evolution. Cambridge University Press, Cambridge.

GEORGES, M., LEQUARRE, A. CASTELLI, M., HANSET, R. AND VASSART, G. 1988. DNA fingerprinting in domestic animals using four different minisatellite probes. Cytogenet. Cell. Genet., 47, 127-131.

GILBERT, D. A., LEHMAN, N., O'BRIEN, S. J. AND WAYNE, R. K. 1990 Genetic fingerprinting reflects population differentiation in the California Channel Island fox. Nature, 344, 764-767.

GILBERT, D. A., PACKER, C., PUSEY, A. E., STEPHENS, J. C. AND O'BRIEN, S. J. 1991. Analytical DNA fingerprinting in lions: parentage, genetic diversity, and kinship. J. Hered., 82, 378-386.

HARWOOD, J. 1987. The status and management of seal stocks in Great Britain. In: CIC Coastal Seal Symposium, Oslo, pp. 23-36.

HOELZEL, A. R. AND DOVER, G. A. 1991. Genetic differentiation between sympatric killer whale populations. Heredity, 66 191-195.

HOELZEL, A. R., HALLEY, J., O'BRIEN, S. J., CAMPAGNA, C., ARNBOM, T., LE BOEUF, B., RALLS, K. AND DOVER, G. A. 1993. Elephant seal genetic variation and the use of simulation models to investigate historical population bottlenecks. J. Hered., 84, 443-449.

JEFFREYS, A. J., ROYLE, N. J., WLSON, v. AND WONG, z. 1988. Spontaneous mutation rates to new length alleles at tandemrepetitive hypervariable loci in human DNA. Nature, 332 , 278-281.

JEFFREYS, A. J., WILSON, v. AND THEIN, S. L. 1985a. Hypervariable 'minisatellite' regions in human DNA. Nature, 314, 67-73.

JEFFREYS, A. J., WILSON, V. AND THEIN, s. L. 1985b. Individual specific 'fingerprints' of human DNA. Nature, 316, 6-79.

KIRBY, L. T. (ed.) 1990. DNA Fingerprinting; an Introduction. Stockton Press, New York.

LYNCH, M. 1990. The similarity index and DNA fingerprinting. Mol. Biol. Evol., 7, 478-484.

MENOTTI-RAYMOND, M. AND O'BRIEN, S. J. 1993. Dating the genetic bottleneck of the African cheetah. Proc. Natl. Acad. Sci. U.S.A., 90, 3172-3176.

O'BRIEN, S. J., ROELKE, M. E., MARKER, L., NEWMAN, A., WINKLERM, C. A., MELTZER, D., COLLY, L., EVERMANN, J. F., BUSH, M. AND WLDT, D. E. 1985 . Genetic basis for species vulnerability in the cheetah. Science, 227, 1428-1434.

REEVE, H. K., WESTNEAT, D. F., NOON, W. A., SHERMAN, P. W., AND AQUADRO, C. F. 1990. DNA "fingerprinting" reveals high levels of inbreeding in colonies of the eusocial naked mole-rat. Proc. Natl. Acad. Sci. U.S.A., 87, 2496-2500.

REIJNDERS, P. J. H. 1980. The Harbour Seal (Phoca vitulina) population in the Dutch Wadden Sea: size and composition. Neth. J. Sea Res., 10, 223-235.

REIJNDERS, P. J. H., VAN DER HAGE, M., HARWOOD, J., VAN DER HEIJDEN, I. K. G., OLSSON, M., OSTERHAUS, A. D. M. E. AND ROSS, H. M. 1989. Report on the International Workshop Seal Disease Epidemic. Research Institute for Nature Management, Texel.

REIJNDERS, P. J. H. AND LANKESTER, K. 1990. Status of marine mammals in the North Sea. Neth. J. Sea Res., 26, $427-435$

(c) The Genetical Society of Great Britain, Heredity, 74, 647-653. 
SCHONEWALD-COX, C. M., CHAMBERS, S. M., MACBRYDE, B. AND THOMAS, L. 1983. Genetics and Conservation: a Reference for Managing Wild Animal and Plant Populations. Benjamin-Cummings, London.

SOULE, M. E. 1987. Viable Populations for Conservation. Cambridge University Press, Cambridge.

STEPHENS, J. C., GILBERT, D. A., YUHKI, N. AND O'BRIEN, S. J. 1992. Estimation of heterozygosity for single-probe multilocus DNA fingerprints. Mol. Biol. Evol., 9, 729-743.

VAN PIJLEN, I. A., AMOS, W. AND DOVER, G. A. 1991. Multilocus DNA fingerprinting applied to population studies of the minke whale Balaenoptera acutorostrata. Rep. Int. Whaling Comm., Special Issue 13, 245-254.

VAN TREUREN, R. 1993. The Significance of Genetic Erosion for the Extinction of Locally Endangered Plant Populations. Ph. D. Thesis, University of Groningen.
WESTNEAT, D. F., NOON, W. A., REEVE, H. K. AND AOUADRO, C. F 1988. Improved hybridization conditions for DNA 'fingerprints' probed with M13. Nucl. Acids Res., 16, 41-61.

WETTON, J. H., CARTER, R. E., PARKIN, D. T. AND WALTERS, D. 1987. Demographic study of a wild house sparrow population by DNA 'fingerprinting'. Nature, 327, 147-149.

wilcove, D. C., McClELlAND, M. AND DOBSON, A. 1986. Habitat fragmentation in the temperate zone. In: Soulé, M. E. (ed.) Conservation Biology: the Science of Scarcity and Diversity, pp. 237-256. Sinauer, Sunderland, MA.

WILLIAMS, J. G. K., KUBELIK, A. R., LIVAK, K. J., RAFALSKI, J. A. AND TINGEY, S. v. 1990. DNA polymorphisms amplified by arbitrary primers are useful as genetic markers. $\mathrm{Nucl}$. Acids Res., 18, 6531-6535. 